\section{Illness experiences of persons with chronic obstructive pulmonary disease: self-perceived efficacy of home-based pulmonary rehabilitation}

\author{
Experiência da enfermidade de pessoas com \\ doença pulmonar obstrutiva crônica: eficácia \\ autopercebida de um programa de reabilitação \\ pulmonar domiciliar
}

\section{Experiencia de la enfermedad de personas con enfermedad pulmonar obstructiva crónica: eficacia auto-percibida de un programa de rehabilitación respiratoria}

Juliana Maria de Sousa Pinto 1,2 Ana Martín-Nogueras 2 Marilyn Nations 3

\footnotetext{
${ }^{1}$ Centro de Ciências da Saúde, Universidade de Fortaleza, Fortaleza, Brasil. 2 Escuela Universitaria de Enfermería y Fisioterapia, Universidad de Salamanca, Salamanca, España.

3 Programa de Pós-graduação em Promoção da Saúde, Universidade de Fortaleza, Fortaleza, Brasil.

Correspondence J. M. S. Pinto Av. Washington Soares 1321, Fortaleza, CE 60811-905, Brasil.

jumsp@hotmail.com
}

\begin{abstract}
This qualitative study explores the illness experiences, the efficacy of pulmonary rehabilitation as perceived by patients with chronic obstructive pulmonary disease (COPD) and their rationale for improvements in health. 23 patients participated in a daily, three-month home-based pulmonary rehabilitation. A pre-post self-perceived assessment of efficacy was conducted. Semi-structured interviews, illness narratives and participant-observation provided a "dense description" of patients' lived-experience before and after the program. Interviews and narratives were tape-recorded, transcribed and coded. Qualitative data was subjected to "thematic content analysis" and "contextualized semantic interpretation". Patients compare functional status before and after falling ill, experience loss, stigma and depression, describe health improvements and judge the pulmonary rehabilitation's efficacy. Giving voice to chronically-ill patients, as individuals, is needed. To reduce clinical conflicts, health professionals should encourage illness narratives and value their patients' livedexperience.
\end{abstract}

Chronic Obstructive Pulmonary Disease; Rehabilitation; Home Nursing; Qualitative Research

\section{Resumo}

Este estudo qualitativo explora as experiências com a enfermidade, a eficácia da reabilitação pulmonar percebida por pacientes com doença pulmonar obstrutiva crônica (DPOC) e sua racionalidade sobre a melhora da saúde. Vinte e três pacientes participaram de um programa de reabilitação pulmonar de três meses, diário, em domicilio. Foi realizada uma pré e pós-avaliação de sua eficácia. Entrevistas semiestruturadas, narrativas de enfermidade e observação participante forneceram uma "descrição densa" da experiência vivida pelos pacientes antes $e$ depois do programa. As entrevistas e narrativas foram gravadas, transcritas e codificadas. Os dados qualitativos foram submetidos à "análise temática de conteúdo" e "interpretação semântica contextualizada". Os pacientes comparam o seu estado funcional antes e depois da doença, a experiência perdida, o estigma e a depressão, descrevem a melhora da saúde e julgam a eficácia da reabilitação pulmonar. É necessário dar voz aos pacientes crônicos como pessoas. Os profissionais de saúde devem obter narrativas da enfermidade e valorizar suas experiências de vida.

Doença Pulmonar Obstrutiva Crônica; Reabilitação; Assistência Domiciliar; Pesquisa Qualitativa 


\section{Introduction}

Chronic obstructive pulmonary disease (COPD) is a preventable and treatable disease which progressively and irreversibly restricts airflow 1 . Tobacco smoking is its principal cause ${ }^{1}$. Disease severity is classified by the Global Initiative for Lung Obstructive Disease (GOLD) as mild, moderate, severe or very severe 1 . Lung capacity is measured by the ratio $\left(\mathrm{FEV}_{1} / \mathrm{FVC}\right)$ of forced expiratory volume in one second $\left(\mathrm{FEV}_{1}\right)$ to forced vital capacity (FVC) ${ }^{2}$. COPD's chronic suffering, physical limitations and psycho-social trauma ${ }^{3}$ are treated with medication and smoking cessation. Pulmonary rehabilitation has proven effective in inpatient, outpatient and home settings ${ }^{1}$ and is associated with quality of life (QoL) improvements as assessed by the Saint George Respiratory Questionnaire (SGRQ) 4, Chronic Respiratory Questionnaire (CRQ) 5, walking and/or cycle ergometry tests 6 and spirometry ${ }^{2}$. Increased scores on QoL and exercise tolerance tend to outpace pulmonary function 7 improvements.

Despite increasing qualitative studies of COPD $8,9,10,11$, its human calculus is poorly understood. What is lacking is a dense ethnographic description of COPD as a "cultural idiom of distress" 12. Medical anthropologists have revealed that providers' and patients' constructions of disease and illness, respectively, often contest each other 3,13,14. In 1977, Eisenberg 15 first drew a distinction between the professional biomedical notion of disease and popular ideas of illness. The following year, Kleinman et al. 16 illustrated critical differences between disease and illness. Disease is configured, objectively, as an alteration(s) in a patient's anatomical structure or physiological functioning. Illness, in contrast, is the subjective human experience of living with the malady. What matters here is how the disorder is perceived, experienced and treated by the person and family members in daily life. Illness is necessarily polysemic and multifaceted. Medical anthropologists 17,18 speak of "social suffering" to link individual experience of pain and distress to the wider social events and structural conditions that are often the ultimate sources of human misery.

How is the illness experience constructed and how does it vary between individuals and across distinct ethnic/cultural groups? 3,19,20. Does the health professionals' dominant discourse about COPD de-legitimize the opinion of those suffering its aftermath 21? Giving voice to patients, as individuals, prompting their illness narratives 22 , valuing their lived-experience and improving their social suffering can help health professionals to reduce clinical conflicts and promote humanized patient-centered care $3,23,24,25,26,27$.

This qualitative study reveals the human illness experience of COPD and its impact on daily living. It describes how severely-ill patients subjectively perceive, evaluate and critique the therapeutic efficacy of in-home pulmonary rehabilitation.

\section{Methods}

This study is part of a descriptive clinical investigation and was undertaken between October 2009 and June 2011 in a hospital-based pulmonary service in Salamanca, Spain. During scheduled appointments, lung specialists selected patients who met four criteria: (1) severe or very severe COPD diagnosis 1; (2) present no cognitive or mental conditions prohibiting participation; (3) eligible for home-based pulmonary rehabilitation and; (4) never previously participated in pulmonary rehabilitation. 41 patients were randomized into treatment (TG) and control (CG) groups for the clinical/epidemiological assessment (Table 1).

Of 23 TG patients, all (100\%) agreed to be interviewed in-depth about their COPD experience (Table 2 summarizes the socio-demographic profiles). Initial contact was made at the hospital followed-up by a home visit when informed consent was obtained. After establishing rapport with informants, a semi-structured interview was conducted to probe participants' lifestyle prior to COPD, disease onset, daily-life limitations, concerns/fears, social relations and pulmonary rehabilitation's self-perceived efficacy.

\section{In-home pulmonary rehabilitation intervention}

Since no pulmonary rehabilitation program existed in this region of Spain, an innovative, daily, three-month home-based intervention was implemented. A protocol of stretching, aerobics and strength exercises were taught at home, eliminating the trip to the city and its medical center. Patients' stairs, static bicycle, unused treadmill and existing neighborhood streets were used for aerobic training. Weights were provided for strength exercises and adjusted to the patient's physical condition. A simpleto-read COPD guideline and calendar with the dates of the physiotherapist's visits were provided and breathing techniques were demonstrated. Strategies for inserting exercises into daily activities were also shared. Initially, two visits were conducted during the first two weeks to ensure patients had adapted to the exercises 
and were performing movements correctly, confidently and without fear.

\section{Self-perceived efficacy evaluation}

Utilizing a semi-structured interview 28 , illness narrative 22 and participant-observation 29 , researchers constructed a "dense description" of each patient's lived-experience. What was it like to live without the breath-of-life? What difficulties of daily-life might he/she face? How might the pulmonary rehabilitation have relieved - or not - their breathing problems? To answer these queries, one-hour in-depth interviews were conducted before and after the pulmonary rehabilitation. Pre-intervention open-ended interviews asked informants to describe: (1) their life before COPD; (2) its onset and course over time; (3) their day-to-day living with it. Interviews after pulmonary rehabilitation inspired informants to tell about: (4) their pulmonary rehabilitation experience; (5) changes noticed before and after it and; (6) possible reasons for changes, if any. At appropriate moments, informants were coaxed to freely narrate their illness experience. This permits informants to order facts and attribute meanings they judge relevant to their existence, eschewing pitfalls of static illness models or representations 22,30. Participant-observation of the patients' lives (i.e. interacting with loved ones, fixing meals, inhaling oxygen, taking medication, exercising, etc.) not only contextualized data but immersed researchers in local realities 31 . These qualitative approaches aimed to capture their subjective view of COPD and pulmonary rehabilitation's efficacy, if any.

Interviews were tape-recorded and transcribed. Observations were registered in a field diary and expanded into descriptive text. Qualitative data was organized and codified according to Content Analysis 32; four categories emerged: (1) subjective GOLD standard; (2) death of normal life; (3) pulmonary rehabilitation's self-perceived efficacy and; (4) rationality for self-perceived efficacy. Data analysis was inspired by Bibeau \& Corin's 33 "contextualized semantic interpretation" which connects patients' experience to systems of significance and actions taken, or not, within existing macro-structural constraints. This study was approved by the Ethics Research Committee

Table 1

Patients' clinical characteristics.

\begin{tabular}{|c|c|c|c|c|}
\hline \multirow[t]{2}{*}{ Variables } & \multicolumn{2}{|c|}{ Treatment group $(n=23)$} & \multicolumn{2}{|c|}{ Control group $(n=18)$} \\
\hline & $\mathrm{n}$ & $\%$ & $\mathrm{n}$ & $\%$ \\
\hline \multicolumn{5}{|l|}{ COPD severity } \\
\hline Severe & 9 & 39.1 & 10 & 55.6 \\
\hline Very severe & 14 & 60.9 & 8 & 44.4 \\
\hline \multicolumn{5}{|l|}{ Comorbilities } \\
\hline Hypertension & 6 & 26.1 & 4 & 22.2 \\
\hline Diabetes & 2 & 8.7 & 2 & 11.1 \\
\hline Osteoporosis & 2 & 8.7 & 4 & 22.2 \\
\hline Cardiac disease & 7 & 30.4 & 5 & 27.8 \\
\hline \multirow[t]{2}{*}{ Oxygen therapy } & 12 & 52.2 & 8 & 44.4 \\
\hline & Mean & SD & Mean & SD \\
\hline Age & 68.91 & 9.24 & 71.94 & 7.64 \\
\hline Height (m) & 1.64 & 0.07 & 1.65 & 0.07 \\
\hline Weight (kg) & 69.87 & 9.58 & 71.50 & 14.38 \\
\hline BMI (kg/m²) & 26.07 & 3.30 & 26.42 & 5.05 \\
\hline $\mathrm{FEV}_{1}(\mathrm{I})$ & 0.89 & 0.19 & 0.94 & 0.22 \\
\hline $\mathrm{FEV}_{1}$ (\%pred) & 33.93 & 7.13 & 35.52 & 9.19 \\
\hline FVC (I) & 2.51 & 0.80 & 2.36 & 0.59 \\
\hline FVC (\%pred) & 74.19 & 19.64 & 67.5 & 16.97 \\
\hline
\end{tabular}

BMI: body mass index; $\mathrm{FEV}_{1}$ : forced expiratory volume in one second; FVC: forced vital capacity; pred: predicted;

SD: standard deviation. 
Table 2

\begin{tabular}{|c|c|c|}
\hline Variables & $\mathrm{n}$ & $\%$ \\
\hline \multicolumn{3}{|l|}{ Gender } \\
\hline Male & 22 & 95.7 \\
\hline Female & 1 & 4.3 \\
\hline \multicolumn{3}{|l|}{ Marital status } \\
\hline Single & 2 & 8.7 \\
\hline Married & 21 & 91.3 \\
\hline \multicolumn{3}{|l|}{ Education } \\
\hline No education & 6 & 26.1 \\
\hline Primary school & 13 & 56.5 \\
\hline High School & 1 & 4.3 \\
\hline University studies & 3 & 13.1 \\
\hline \multicolumn{3}{|l|}{ Occupation } \\
\hline Employment & 4 & 17.4 \\
\hline Retired & 19 & 82.6 \\
\hline \multicolumn{3}{|l|}{ Income * } \\
\hline$<$ US\$1,308 & 13 & 56.5 \\
\hline US\$1,308-2,616 & 6 & 26.1 \\
\hline$>$ US\$2,616 & 4 & 17.4 \\
\hline \multicolumn{3}{|l|}{ Residence } \\
\hline Urban zone & 13 & 56.5 \\
\hline Rural zone & 10 & 43.5 \\
\hline Use of public transportation & 11 & 47.8 \\
\hline
\end{tabular}

* Income (in $€$ ) equivalent in US\$.

of the University of Salamanca. All informants' names are fictitious.

\section{Results}

Informants experience COPD in subjective ways. Patients scrutinize subtle changes over time in their functional status and critique the intervention's impact on their daily lives. They identify their baseline health status, or "GOLD standard", as "leading a normal healthy life" before diagnosis and before suffering any physical, emotional or social aftermath. They mentally compare their functional capacity upon falling ill with their baseline standard, identify diminished pulmonary capacity and other negative health impacts, pinpoint and describe gains in breathing capacity and other improvements. Moreover, patients judge pulmonary rehabilitation's efficacy.

\section{Subjective GOLD standard}

While informants' subjective construction of COPD is mutable and multifaceted - "It's not the same every day or every time or even in the same day!" - they uphold a GOLD standard comparing a normal healthy life before illness to their health status after diagnosis to determine the development and severity of COPD. Informants define a normal life as having the capacity to: work, cook meals, perform household chores, maintain social relationships, travel with friends, participate in an over-60-club and have a sex life. Señor Jorge, 69 , an ex-fireman who led an active life before severe COPD $\left(\mathrm{FEV}_{1}=33.4 \%\right.$ pred $)$ laments a restriction on daily activities since disease diagnosis: "I used to be very active and enjoyed doing the housework all by myself. But now, I can't do things without asking for help, like taking down and washing dirty curtains. I can't stand all that walking!" Now he is the boss, ordering his son to execute orders. Señor Francisco, 76, retired, suffering very severe COPD $\left(\mathrm{FEV}_{1}=34.3 \%\right.$ pred $)$ and oxygen-dependent (2.5L/min;16hours/daily), fails to perform as before; he regrets his incapacity to perform routine chores: "Before [COPD], I used to cook, clean windows, sweep... But the other day, I was just peeling potatoes and carrots and I tired. This never made me tired before!" Subjectively comparing how they felt prior to COPD onset and since diagnosis, patients astutely assess the damage provoked over time.

\section{"Death" of normal life}

When doctors diagnose COPD, normality is shattered abruptly: "This disease ruptured the rhythm of my life?" exclaims one patient diagnosed at 40 years of age - the prime of life. Receiving the clinical verdict was like being stamped with a validity date. Physical limitations, emotional upheavals and social damage resonate throughout life dimensions, as if they were literally dying. Sadness and depression set in. Some isolate themselves for days on end. Paying bills or signing a document requires arduous effort.

Informants perceive their body changing from muscular loss and associated fatigue. Señor Ignacio, 72 , retired, $57 \mathrm{~kg}$ (weight) and $1.70 \mathrm{~cm}$ (height) explains: "My muscles started degenerating. My legs, arms, body fat and muscle mass were disappearing before my eyes! I became so fatigued!" The construction worker now suffers very severe emphysema $\left(\mathrm{FEV}_{1}=27.7 \%\right.$ pred $)$. He is traumatized by the disease's impact on his body: "I completely lost my body fat and my strength because of this disease! I'm all bones...nothing else! My legs look like little sticks. My God, (...) my chest is totally caved in! Just look at my arms! I don't have any strength left! Little by little, I've lost everything!" Performing daily activities challenges this previously energetic worker. When at home alone, he 
is too exhausted to get up, answer the intercom and unlock the door when the bell rings.

Far from $\mathrm{FEV}_{1}$, informants subjectively recognize debilitated functional status by gauging the degree of physical limitation in everyday tasks: walking, talking, dressing, climbing stairs, making the bed, washing dishes, shopping, eating or having sex. Seriously-ill Señor Ignacio plants himself on the sofa and shuffles back-and-forth between the bedroom and bathroom. It is a strenuous task to even raise his spoon heaped with food from plate to mouth!: “Lately, I'm too fatigued. I get tired holding the spoon up to my mouth for so long! Everything I eat must be mashed. I can't even eat!" COPD transfigured this gregarious man into a bitter scrooge. Oxygen-dependent $(1 \mathrm{~L} / \mathrm{min}$; 17hours/daily), Señor Manolo, 62, gauges disease severity on the basis of a radical change in his normal lifestyle. He now struggles to overcome physical limitations: "I can't lead a normal life, I can't do $90 \%$ of the things I used to do... making the bed, washing dishes, mopping the floors. It's tiring. I get so exhausted when I reach the top of the stairwell. I must quickly open the window to get some air to keep from suffocating. My daughter must give me oxygen!" Señor Miguel Angel, 72, a successful businessman suffers severe COPD $\left(\mathrm{FEV}_{1}=34.1 \%\right.$ pred $)$. While working diligently at his desk, he takes illness vacation: "When I'm sitting still, I forget I'm ill". He feels normal again. The slightest physical demand - sliding out of a taxi's back seat or during sexual intercourse locks-up his body: "I'm feeling fine...then must gather-up my belongings, open the taxi door and slide out. But I'm already tired! And having sex (...) weeks and weeks go by and I can't muster-up the energy!"

Informants are aware that COPD damages their psycho-social wellbeing; they are "illness prisoners", suffocated, insecure, limited and unable to lead a normal life. Negative emotions unleash fatigue and dampen motives to self-care. The once active are now dependent upon spouses and relatives to pay bills and undress, shower and groom them. Interpersonal dynamics and household structures change. Grandfather Señor Ruben, 53, felt emotions jolt when doctors diagnosed COPD - a step toward suicide: "It's killing me. Really tough! If I was 60 when it was diagnosed, it would be no big deal... but I was 50! I'm still young and on top of the world! Then, suddenly, you're too exhausted to do anything! You see yourself inactive... it breaks you in two. Don't think I haven't thought about it [suicide]. I've asked myself: 'What are you doing here?' Then, I remember my granddaughter and the bad thoughts escape my mind!" Patients distance their friends, quit jobs and avoid over-crowded bars and public places. Señor Juan, 70, an oxygen-dependent retiree (1L/min; 24 hours/daily), is burdened by his air tank; he must push it when venturing outside. Jokingly, he refers to his severe COPD $\left(\mathrm{FEV}_{1}=36 \%\right.$ pred $)$ as a "window shop illness". Feeling stigmatized as he strolls the streets, he stops, rests and catches his breath, pretending to window shop to shield himself from curious shoppers' stares.

\section{Pulmonary rehabilitation self-perceived efficacy}

Chronically-ill patients evaluate pulmonary rehabilitation efficacy using myriad criteria other than $\mathrm{FEV}_{1}$ improvements on medical charts. In narratives, informants weigh health benefits and therapeutic efficacy on at least 11 meaningful changes in: (1) thorax anatomical structure; (2) breathing patterns; (3) fear of death by "suffocation"; (4) muscular mass; (5) ease of movement; (6) control over life; (7) dependency state; (8) selfesteem; (9) feelings of happiness; (10) desire to live; and (11) sense of "normalcy".

All informants perceive respiration improvements resulting from breathing techniques. They perceive the benefits of pulmonary rehabilitation when panic and fear of death by suffocation subsides. Others judge efficacy based on perceived muscular changes and their ability to walk, get dressed, shower, shave, brush their hair and climb stairs without fatigue: "When exercising, my hands and fingers don't fall asleep anymore. When stretching, I've noticed my legs don't knot-up". Although he disdains exercise, after three months exercising Señor Julio, 59, married, with very severe $\mathrm{COPD}\left(\mathrm{FEV}_{1}=23 \%\right.$ pred $)$, rates pulmonary rehabilitation efficacy based on improved ease and a greater range of physical movement: "I was going downhill...couldn't move easily. But with exercising, it came back! I see the benefit with my own eyes!" Others perceive increased control over their bodies and life. The looming uncertainty of breathing is controlled by mastering pulmonary functioning through exercise. Imprisoned patients feel liberated when they can breathe unencumbered. After overcoming physical limitations, they report feeling calmer, more secure and happier. A subjective surge of pleasure invades their souls: "I feel like a new man!" Finally, informants judge pulmonary rehabilitation as efficacious if it resuscitates their sense of normal life before illness: "I still depend on others but I can live a more-or-less normal life!" 


\section{Rationality for self-perceived efficacy}

Easy access to medical care/health information and enhanced quality care are the reasons for the efficient pulmonary rehabilitation program. For $47.8 \%$ living in rural towns, improved physical access to professional care was a clear advantage. For most (47.8\%) patients who are chronically-ill and depend on public transport, the convenience of home-based care by a physiotherapist is obvious. After its implementation, complaints of access barriers and out-of-pocket transportation costs are nil: "It's so good the physiotherapist comes here [patient's home] because I can't move around by car anymore!" Señor Raúl, 72, retired, living $60 \mathrm{~km}$ away from the hospital, suffering very severe COPD and oxygen-dependent (1L/ min; 17hours/daily) affirms that home-based pulmonary rehabilitation improved his compliance: "If it wasn't for you coming to my home, I certainly wouldn't go to the city, too tiring!" One patient claims traveling to the city increases health risks: "I just can't bring myself to travel to the city every day (...) too far back-and-forth for my liking!" Another alleges bad winter weather deters compliance to hospital-based pulmonary rehabilitation. Señor Diego, 73, residing in a village $16 \mathrm{~km}$ from the hospital, suffers severe COPD $\left(\mathrm{FEV}_{1}=35.3 \%\right.$ pred $)$ and benefits from home-care: "In the winter, with the cold, it's very dangerous driving to the hospital. It's far more convenient for the therapist to come to my house".

Informants attribute pulmonary rehabilitation efficacy to enhanced access to information about their debilitating health condition. During physiotherapist's home visits, patients feel at ease to ask questions, solicit information and eliminate doubts about COPD.

Patients judge pulmonary rehabilitation's efficacy based on its quality of care, citing three advantages. Firstly, the therapeutic context is a comfortable home instead of an intimidating hospital. At home, they are less of a patient and more a person, surrounded by beloved caretakers. They receive therapists as special guests. Señor Raúl says: "It's better here at home! It's more peaceful and more comfortable". Home is a place believed to be conducive to healing the sick. Secondly, pulmonary rehabilitation's flexible scheduling, personalized activities and adaptation to home conditions all improve the quality of care. Unlike hospital protocols, pulmonary rehabilitation is tailored to patients' daily time schedules, locally-available equipment and individual capacities. Rather than imposing a set of movements and repetitions, pulmonary rehabilitation allows patients to negotiate with the physiotherapist, skirting unrealistic goals. Pulmonary rehabilitation's flexibility inserts the patient's voice - and critical feedback - into program design: "These exercises people can actually do! You can adjust the weight and benefit more! It's a big difference from ordering, 'You must walk 5km a day!' I just give-up... can't do it!" Instead of demanding that patients buy expensive and unfamiliar equipment, apparatuses on hand (e.g. bike, stairs, corridors) are utilized. There is no need to spend money with costly equipment. Such adaptability, informants affirm, is responsible for pulmonary rehabilitation's adoption by the chronically-ill. And, thirdly, pulmonary rehabilitation's quality care out-ranks conventional hospital services, say patients, because the therapeutic relationship is built on open-communication and interpersonal trust. Formal interviews and structured clinical examinations are replaced by informal exchanges, sealing a bond of friendship and caring. Respectful of doctors, Señor Raúl says: "Although I trust doctors at the hospital, I've spoken much more openly to the physiotherapist who visits me!" According to patients' critique, pulmonary rehabilitation's efficacy is due to reaching-out to COPD suffers and sharing intelligible health information in their natural environment.

The following narratives express the personal experience of two persons with COPD, the diagnosis and the changes in life as well as the experience with the Home-Based Pulmonary Rehabilitation Program. Señor Pablo, 71, retired, suffering severe COPD $\left(\mathrm{FEV}_{1}=29 \%\right.$ pred $)$ is a COPD prisoner - trapped inside his body without free movement when connected to the oxygen machine (1.5L/min; 18hours/daily). After diagnosis, he claims he is "more demanding and intransigent (...) the illness changed my character" and describes the changes in his life: "I used to go out with friends. We would chat and drink wine. I have to stop all of this because my friends can't slow down for me and I can't keep up pace with them. And forget about going to the park with the grandkids (...) they slip away from my hand and run away! Imagine what could happen to them?" He felt bad in the moment of the diagnosis and day by day the COPD was keeping him at home: "The pulmonologist saw the file, the results of the spirometry, the x-rays and he said: 'You should only walk when necessary, eh! Don't even think about exhausting yourself'. Then he said: 'Don't even think about going up the stairs. I live on the first floor and there is a lift. Well, I was so bad that he also prohibited me from going up and down slowly so that I wouldn't get exhausted. In other words, he made it sound really bad. (...) I've sat here often... I should go for a walk, damn it, but my legs hurt. I'm going to get tired, I mean, I would talk myself out of it". After three-months of pul- 
monary rehabilitation, he credits the flexible exercise schedule of the pulmonary rehabilitation for his improvement: "The way they developed it [pulmonary rehabilitation] is very good for each one of the patients because they can do it in the morning, for example. There are some that can't do it in the mornings because of whatever housework they might have to do so they do it in the afternoon. I think they are exercises that people can do because I'm sure that if you tell me 'you have to walk 5km a day', in the end, I know I'll give it up because I just can't do it".

Señora Lucía, 53, a retired short-order cook suffering severe COPD $\left(\mathrm{FEV}_{1}=39.8 \%\right.$ pred $)$, recognizes how she was before the pulmonary rehabilitation and after participating in it: "I used to see myself in bed or in a chair and now I'm back in charge of my life! I'm now independent! I can wash myself, get dressed and go out! This used to be the most difficult thing in the world! (...) My thorax opened. I felt much better [after pulmonary rehabilitation]. They pulled a plug out of my chest! I learned to breathe: exhaling instead of inhaling while I'm walking, making the bed, bending over. I used to do it the other way around! Now, going up stairs takes longer but I'm rested and my tongue isn't hanging out! Before, I panicked with the thought of suffocating without knowing what to do! Now, I know that when out of breath, I stop, breathe, calm down and try not to get upset about silly little things in life! I'm not afraid anymore! I can control my body which I couldn't do before and... I felt so awful! (...) Even with obvious limitations, little-by-little, you gain control over your life again! No more depending on anybody! (...) At first, I was totally destroyed but now I'm so happy on a physical and mental level! I'm more motivated! I had my hair done! Now, I want to live, to fight, to go out, do everything!" She also has her personal opinion about the pulmonary rehabilitation and its importance in giving her knowledge about her illness: "I don't know if doctors liked the program but, for me, it was great! I'm very happy. It's been so liberating for me. Even though I was diagnosed with emphysema five years ago, nobody told me anything! They were so busy and rushing around. All they said was it's a chronic illness, there's NO cure, it attacks slowly! But I didn't get any instructions about what I could or couldn't do or what could help me live my normal life! For me, this program has been phenomenal because I know what I have and how to control it!"

\section{Discussion}

This qualitative research in health reveals a self-perceived GOLD standard of pulmonary functioning constructed by chronic-ill Spanish persons 11. Ironically, the subjective idiom of distress 12 differs from - even contests - the internationally-recognized biomedical GOLD standard 1. Lay benchmarks of positive health compares subtle changes in life worlds before illness and after COPD diagnosis - normal life ruptures abruptly. Changes in life's rhythm, body mass, emotional states and social activities are perceived, triggering a symbolic death of normalcy. Inhaling the breath-of-life is forever altered. Patients experience significant losses: active living, muscle mass, vital energy, self-esteem, friends and joyful moments. They report feeling suffocated, dependent on others and stigmatized - prisoners of their own illness. Many suffer low morale and depression. Employing their own GOLD standard, gravely-ill informants critique pulmonary rehabilitation. Empowered with new knowledge, participants judge pulmonary rehabilitation's efficacy in resuscitating a pre-illness way-of-life. Any breathing and QoL improvement is rationalized according to local knowledge not biomedical findings 34 .

This study innovates by taking a patient-centered 24,25 approach, amplifying a restrictive disease focus. The reference point is the human person not the physical body ${ }^{35}$. The principles of "patient-centered" care are: (1) a health professional's exploration and interpretation of disease and the patient's illness experience, including the feeling of being sick, illness impact on daily-life and expectations of what should be done; (2) a holistic view of the person; (3) a search for common understanding of the problem and its resolution; (4) incorporation of preventive and health promotion measures; (5) enhancement of the therapist-patient relationship and; (6) time and cost effectiveness 25 . As our study confirms, care focused on the patient's reality is a viable alternative to professionally-controlled treatment confined to hospitals. Our pulmonary rehabilitation adapts treatment to in-home and local resources, increasing care for severely-ill, oxygen-dependent and mobility-restricted individuals. Pulmonary rehabilitation enforces autonomy, freechoice and control over one's health - principals of Health Promotion 36. It compassionately combats human suffering from chronic disease, stereotyped by health-professionals as frustrating, and incurable 37 . In illness narratives, informants express sentiments and describe traumatic experiences heretofore missing in strictly biomedical renditions 3,14,21,38. The authenticity of patients' voices reveals the human trauma of COPD.

Such meaning-saturated evidence is as significant, we argue, as standardized calculations, statistical probabilities and p-values. The human 
calculus of COPD is incalculable. Triangulation of anthropological methods enhanced our comprehension of the patient's subjective world of suffering and victories over physical limitations. A critical, close-up evaluation from the patient's emic perspective 39 amplifies classic disease-oriented assessments, humanizing clinical care. This critical theme, however, did not figure into our original research design, which was an oversight. Probing pulmonary rehabilitation's self-perceived efficacy emerged during data analysis. Flexibility and improvisation, embedded in qualitative methods, allowed us to unleash the human spirit and reveal a poignant lay critique locked inside debilitated physical bodies - an element of surprise in our research.

While lay rationalities about chronic illness and treatment efficacy were explored 6,7,27, this study contributes by uncovering a subjective "GOLD standard" heretofore unreported. It is patients' own critical comparison of life before and after COPD, pinpointing subtle, albeit significant changes over time in daily functioning. Recall that retired Señor Pablo critiques his diminished capacity to stroll at the same pace with friends or to stop his grandchildren's hands from slipping out of his grasp and them running off. Even though some studies reveal restrictions and losses in COPD patients' emotional and social realms 13,14 , this anthropological study details the meaning of functional limitations in real life contexts. It probes what really matters 40 .

Interviews with 12 moderate to severe COPD patients in the United States 41 revealed that physical changes not only made daily activities more difficult but also challenged patients' personal integrity, feelings of effectiveness and world connectedness. Corroborating our results, authors also found losses of patients' functionality and comparisons of functional performance before and after diagnosis 41 . Another study using semi-structured, in-depth interviews with 11 end-stage COPD patients 42 , identified breathlessness as the most frequent physical limitation. Breathing anxiety is precisely what Señor Manolo reports feeling after climbing stairs. Rather than focus on disease-provoked limitations and difficulties, patients' emic viewpoint 39 emphasizes a shift from normal to limited-life - a new functional state. Ten COPD patients in the UK 43 reported that symptoms vary from day-to-day and even hour to hour; daily activities are not as frequent as before: "I used to bathe daily... I miss it!" Like our patients, her informants were less likely to socialize, take holidays and enjoy a normal life. Lucia's frustration at being dependent on her husband for personal care is echoed in an urban slum in
Fortaleza, Brazil 3, where patients experience low self-esteem due to dependency on caregivers and oxygen tanks. Bathing, shopping or attending church are strenuous tasks. Moreover, as curious shoppers gawked at Señor Juan, he suffered the stigma of a 'window shop' illness as did 18 COPD patients in Norway 38; doctors berated and blamed them for smoking: "You feel that some doctors think it is simply self-inflicted", they bemoaned. Because our patients are also ex-smokers, we suspect accusatory victim blaming 44 may also be at play - especially in smokefree healthy environments. The loss of normal life is painful for patients. In the Social Origins of Depression 45, the authors conclude that loss and disappointment are the central features of most events bringing about clinical depression long-term, not short-term, threats correlated with the experience of loss. Loss of an imagined preceding healthy life after being diagnosed with the life-threatening COPD may trigger clinical depression in forlorn patients.

Our informants' subjective critiques of pulmonary rehabilitation's efficacy - like other COPD patients in different cultural settings $13,23,46$ - affirm its restorative capacity. It promotes human well-being contends Señora Lucía who feels happier, more motivated to live and liberated from COPD after pulmonary rehabilitation; she regains control over her body and life. A patient feels like a new man receiving a second lease of life after pulmonary rehabilitation. Other researchers report similar self-perceived benefits from pulmonary rehabilitation, mostly those that are clinical and hospital-based interventions. After an eight-week outpatient pulmonary rehabilitation 13 participants reported increased confidence and control over breathing crises, improved mobility and physical capacity to perform household tasks; as participation in events improved complaints of social isolation diminished. After an eight-week outpatient pulmonary rehabilitation based in a general hospital, 7 British COPD patients reported a reduction in symptoms, increased self-confidence, improved control over breathlessness, better social interaction and emotional well-being 23 . Unlike these evaluations, our pulmonary rehabilitation was home-based and the 23 patients not only endorsed pulmonary rehabilitation but adamantly favoured home-based over hospital treatment. After one-year pulmonary rehabilitation, 50 very severely-ill COPD patients (also in Spain) report subjective evidence of enhanced exercise tolerance, reduced dyspnoea and QoL improvement 46 . Because health promotion is predicated on creating favourable environments which are conducive to healthier living 36 , there is an 
urgency to critically evaluate - from the patients' vantage point - home-based pulmonary rehabilitation in diverse cultural contexts.

Our results are relevant to pulmonary rehabilitation team professionals since they reveal patients' private perceptions and experiences of loss, guilt and stigma - the social seeds of depression 45 . As adopted by some pulmonary rehabilitation programs 47,48 , routine screening and treatment of depression by a mental health specialist appears to be essential. Eradicating COPD's social stigma is also a priority. Global measures to combat prejudice, discrimination and social exclusion 49 may also be effective in this context. Uncovering patients' hidden critiques of hospital and home-based pulmonary rehabilitation's efficacy serves as a critical feedback for health professionals. From the patients' vantage point, the caretaking context - a favourable environment - is paramount for promoting health 36 . Results pinpoint a need for adjusting interventions to individual necessities, local realities and available resources. For our informants, empowering lay people with information is a cornerstone of selfcare and health autonomy 50. By incorporating exercises into daily-life, patients quickly perceive small - albeit significant - health improvements.

Besides intriguing insights, this study raises unanswered questions: can home-based pulmonary rehabilitation significantly improve exercise compliance and overall health according to both objective and subjective criteria? Can patients score low on quantitative physical assessment scales yet self-report feeling better by qualitative narrative appraisals? This study suggests patients' GOLD standard and self-perceived judgements about pulmonary rehabilitation's efficacy is pivotal for assessing its overall impact on pulmonary health. Qualitative evaluations open new pathways to penetrate patients' lifeworlds. Giving voice to chronically-ill persons yields a poignant critique and critical clues needed to adjust pulmonary rehabilitation to lived reality - an essential task to humanize clinical care 51.

\section{Resumen}

Este estudio explora las experiencias con la enfermedad, la eficacia de la rehabilitación respiratoria percibida por los pacientes con enfermedad pulmonar obstructiva crónica (EPOC) y su racionalidad para la mejoría en salud. Veintitrés pacientes participaron en un programa de rehabilitación respiratoria domiciliaria durante tres meses. Fue realizada una pre- y posevaluación auto-percibida de la eficacia del programa. Entrevistas semiestructuradas, relatos sobre la enfermedad y una observación participativa proporcionaron una "descripción densa" de la experiencia vivida por los pacientes antes y después del programa. Las entrevistas y relatos fueron grabados, trascritos y codificados. Los datos cualitativos fueron sometidos a un "análisis temático de contenido" e "interpretación semántica contextual". Los pacientes compararon su estado funcional antes y después de la enfermedad, la experiencia perdida, el estigma y la depresión, describen mejorías en la salud y juzgan la eficacia del programa. Es necesario dar voz a los pacientes crónicos en este sentido.

Enfermedad Pulmonar Obstructiva Crónica Rehabilitación; Atención Domiciliaria de Salud; Investigación Cualitativa

\section{Contributors}

J. M. S. Pinto participated in the design, acquisition of data, writing of the article; she read and approved the final version of the manuscript. A. Martín-Nogueras participated in the design and acquisition of data, and read and approved the final version of the manuscript. M. Nations participated in the drafting of the article; analysis and interpretation of the data; writing of the article; and its critical reviewing for important intellectual content; she read and approved the final version of the manuscript.

\section{Acknowledgments}

We thank our informants for sharing their suffering and struggle to overcome COPD and Kenneth Martin for his diligent editorial assistance. Financial support was provided by the University of Salamanca, the Ministry of Foreign Affairs and Cooperation (J. M. S. Pinto) and CNPq (productivity in science grant \#307346/2011-0 M. Nations). 


\section{References}

1. Global Initiative for Chronic Obstructive Lung Disease. Guidelines: global strategy for the diagnosis, management and prevention of COPD. http:// www.goldcopd.org (accessed on Jan/2012).

2. Pierce R. Spirometry: an essential clinical measurement. Aust Fam Physician 2005; 34:535-9.

3. Pinto JMS, Vieira LJES, Nations MK. Breath of life: experience with chronic obstructive pulmonary disease in the context of urban poverty in Fortaleza, Ceará State, Brazil. Cad Saúde Pública 2008; 24:2809-18.

4. Jones PW, Quirk FH, Baveystock CM. The St George's Respiratory Questionnaire. Respir Med 1991; 85:25-31.

5. Wijkstra PJ, TenVergert EM, Van Altena R, Otten V, Postma DS, Kraan J, et al. Reliability and validity of the chronic respiratory questionnaire (CRQ). Thorax 1994; 49:465-7.

6. Ferrari M, Vangelista A, Vedovi E, Falso M, Segattini C, Brotto E, et al. Minimally supervised home rehabilitation improves exercise capacity and health status in patients with COPD. Am J Phys Med Rehabil 2004; 83:337-43.

7. Halpin DM, Tashkin DP. Defining disease modification in chronic obstructive pulmonary disease. COPD 2009; 6:211-25.

8. Rodgers S, Dyas J, Molyneux AWP, Ward MJ, Revill SM. Evaluation of the information needs of patients with chronic obstructive pulmonary disease following pulmonary rehabilitation: a focus group study. Chron Respir Dis 2007; 4:195-203.

9. Halding AG, Heggdal K. Patients' experiences of health transitions in pulmonary rehabilitation. Nurs Inq 2011; 19:345-56.

10. Goodridge D, Hutchinson S, Wilson D, Ross C. Living in a rural area with advanced chronic respiratory illness: a qualitative study. Prim Care Respir J 2011; 20:54-8.

11. Fromer L. Implementing chronic care for COPD: planned visits, care coordination and patient empowerment for improved outcomes. Int J Chron Obstruct Pulmon Dis 2011; 6:605-14.

12. Mark N. Idioms of distress: alternatives in the expression of psychosocial distress: a case study from South India. Cult Med Psychiatry 1981; 5:5-24.

13. Williams V, Bruton A, Ellis-Hill C, McPherson K. The effect of pulmonary rehabilitation on perception of breathlessness and activity in COPD patients: a qualitative study. Prim Care Respir J 2010; 19:45-51.

14. Gysels M, Higginson IJ. The experience of breathlessness: the social course of chronic obstructive pulmonary disease. J Pain Symptom Manage 2010; 39:555-63.

15. Eisenberg L. Disease and illness: distinctions between professional and popular ideas of sickness. Cult Med Psychiatry 1977; 1:9-23.

16. Kleinman A, Eisenberg L, Good B. Culture, illness, and care: clinical lessons from anthropologic and cross-cultural research. Ann Intern Med 1978; 88:251-8.

17. Kleinman A, Das V, Lock M, editors. Social suffering. Berkeley: University of California Press; 1997.
18. Nations M, Gondim APS. "Stuck in the muck": an eco-idiom of distress from childhood respiratory diseases in an urban mangrove in Northeast Brazil. Cad Saúde Pública 2013; 29:303-12.

19. Katz AM, Alegría M. The clinical encounter as local moral world: shifts of assumptions and transformation in relational context. Soc Sci Med 2009; 8:1238-46.

20. Parker DR, Goldman RE, Eaton CB. A qualitative study of individuals at risk for or who have chronic obstructive pulmonary disease: what do they understand about their disease? Lung 2008; 186:313-6.

21. Gardiner C, Gott M, Small N, Payne S, Seamark D, Barnes S, et al. Living with advanced chronic obstructive pulmonary disease: patients' concerns regarding death and dying. Palliat Med 2009; 23:691-7.

22. Kleinman A. The illness narratives: suffering, healing \& the human condition. New York: Basic Books; 1988.

23. Toms J, Harrison K. Living with chronic lung disease and the effect of pulmonary rehabilitation: patients' perspectives. Physiotherapy 2002; 88:605-19.

24. Stewart M. Towards a global definition of patientcentered care. BMJ 2001; 24:444-5.

25. Stewart M, Brown JB, Weston WW, McWhinney IR, McWillian CL, Freeman TR. Patient-centered medicine: transforming the clinical method. Abingdon: Radcliffe Medical Press Ltd.; 2003.

26. Crapo RO, Casaburi R, Coates AL, Enright PL, MacIntyre NR, McKay RT, et al. ATS statement: guidelines for the six-minute walk test. Am J Respir Crit Care Med 2002; 166:111-7.

27. Garrod R, Bestall JC, Paul EA, Wedzicha JA, Jones PW. Development and validation of a standardized measure of activity of daily living in patients with severe COPD: the London Chest Activity of Daily Living scale (LCADL). Respir Med 2000; 94:589-96.

28. Spradley JP. The ethnographic interview. New York: Holt, Rinehart and Winston; 1979.

29. Jorgensen DL. Participant observation: a methodology for human studies. London: Sage Publications; 1989.

30. Lira G, Catrib AMF, Nations MK. A narrativa na pesquisa social em saúde: perspectiva e método. Rev Bras Promoç Saúde 2003; 16:59-66.

31. Geertz CA. The interpretation of cultures. New York: Basic Books; 1973.

32. Neuendorf KA. The content analysis guidebook. Thousand Oaks: Sage Publications; 2002.

33. Bibeau G, Corin EE. From submission to the text to interpretative violence. In: Bibeau G, Corin EE, editors. Beyond textuality: asceticism and violence in anthropological interpretation. Berlin: Mouton de Gruyter; 1995. p. 3-54.

34. Capra F. O ponto de mutação: a ciência, a sociedade e a cultura emergente. São Paulo: Editora Cultrix; 1982. 
35. Uchôa E, Vidal JM. Antropologia médica: elementos conceituais e metodológicos para uma abordagem da saúde e da doença. Cad Saúde Pública 1994; 10:497-504.

36. World Health Organization. The Ottawa Charter for Health Promotion. http://www.who.int/ hpr/NPH.../ottaea_charter.hp.pdf (accessed on Mar/2012).

37. Kleinman A. The social context of chronicity in the illness narratives: suffering, healing \& the human condition. New York: Basic Books; 1988.

38. Halding AG, Heggdal K, Wahl A. Experiences of self-blame and stigmatisation for self-infliction among individuals living with COPD. Scand J Caring Sci 2011; 25:100-7.

39. Geertz C. Local knowledge: further essays in interpretative anthropology. New York: Basic Books; 2000.

40. Kleinman A. What really matters: living a moral life amidst uncertainty and danger. New York: Oxford University Press; 2006.

41. Leidy NK, Haase JE. Functional status from patient's perspective: the challenge of preserving personal integrity. Res Nurs Health 1999; 22:67-7.

42. Habraken JM, Pols J, Bindels PJE, Willems DL. The silence of patients with end-stage COPD: a qualitative study. Br J Gen Pract 2008; 58:844-9.

43. Barnett M. Chronic obstructive pulmonary disease: a phenomenological study of patient's experiences. J Clin Nurs 2005; 14:805-12.

44. Ryan W. Blaming the victim. New York: Parthenon Books; 1971.
45. Brown GW, Harris T. Social origins of depression: a study of psychiatric disorder in women. New York: The Free Press; 1978.

46. Fernández AM, Pascual J, Ferrando C, Arnal A, Vergara I, Sevila V. Home-based pulmonary rehabilitation in very severe COPD: is it safe and useful? J Cardiopulm Rehabil Prev 2009; 29:325-31.

47. Garuti G, Cilione C, Dell'Orso D, Gorini P, Lorenzi MC, Totaro L, et al. Impact of comprehensive pulmonary rehabilitation on anxiety and depression of hospitalized COPD patients. Monaldi Arch Chest Dis 2003; 59:60-5.

48. Hildegarde PD, Maria MO, Jose ML, Bartolome RC. Pulmonary rehabilitation improves depression, anxiety, dyspnea and health status in patients with COPD. Am J Phys Med Rehabil 2007; 86:30-6.

49. Keush GT, Wilentz J, Kleinman A. Stigma and global health: developing a research agenda. Lancet 2006; 367:525-7.

50. Freire P. Pedagogia da autonomia: saberes necessários à prática educativa. São Paulo: Paz e Terra; 1966.

51. Nations MK, Gomes AMA. Cuidado, "cavalo batizado" e crítica da conduta profissional pelo paciente-cidadão hospitalizado no Nordeste brasileiro. Cad Saúde Pública 2007; 23:2103-12.

Submitted on 22/Mar/2013

Final version resubmitted on 18/Oct/2013

Approved on 14/Nov/2013 